\title{
First fossil jewel beetle (Insecta: Coleoptera: Buprestidae) from Middle Miocene deposits in Bulgaria
}

\author{
Nikolay Simov', Mario Langourov², Vladimir Sakalian³, Vladimir Bozukov ${ }^{4}$ \\ (1) National Museum of Natural History, Bulgarian Academy of Sciences, 1 Tsar Osvoboditel Blvd, 1000 Sofia, Bulgaria, \\ simov@nmnhs.com; https://orcid.org/0000-0003-1626-2964 \\ (2) National Museum of Natural History, Bulgarian Academy of Sciences, 1 Tsar Osvoboditel Blvd, 1000 Sofia, Bulgaria, \\ langourov@nmnhs.com; https://orcid.org/0000-0001-6756-3420 \\ (3) Institute of Biodiversity and Ecosystem Research, Bulgarian Academy of Sciences, 1 Tsar Osvoboditel Blvd, 1000 Sofia, \\ Bulgaria, vladimir.sakalian@gmail.com \\ (4) Institute of Biodiversity and Ecosystem Research, Bulgarian Academy of Sciences, 23 Acad. G. Bonchev Street, 1113 \\ Sofia, Bulgaria, vladimir_bozukov@yahoo.com
}

\begin{abstract}
The first fossil jewel beetle discovered in Bulgaria is reported from deposits of the Satovcha Basin dated to the Middle Miocene.
\end{abstract}

Keywords: Balkans, Buprestidae, Miocene, Rhodopes, Satovcha

\section{Introduction}

The present contribution is a continuation of the study of the fossil insects from deposits of the Satovcha Basin dated to the Middle Miocene. Up to now, the fossil dragonflies and March flies were investigated from the region (Nel et al., 2016; Simov et al., 2021).

Here we present the first data of Miocene fossil coleopterans from Bulgaria, which represent also the first record of the fossil representative of the family Buprestidae from the country.

\section{Material and methods}

The studied fossil specimens were collected during the palaeobotanical expeditions in the region of Satovcha in the period 1958-1967, and in the beginning of the 1980s (Nel et al., 2016, Simov et al., 2021).

The Satovcha Basin (Satovcha Graben), which is located on the southern slopes of the western Rhodopes (SW Bulgaria), unfolds to the east from the Satovcha
Village, Blagoevgrad District. The site corresponds to a large, deep, eutrophic freshwater palaeolake (Vatsev \& Pirumova, 1983; Vatsev, 1999). It is filled with Tertiary freshwater sedimentary and volcanic rocks. Two official lithostratigraphic units are recognised in the basin: the Satovcha Formation and the Sivik Formation (Vatsev \& Pirumova, 1983). The Sivik Formation covers the Oligocene volcanics and the sediments of the Satovcha Formation. The sedimentary rocks of the Sivik Formation lie discordantly on them and consist of sandstones, aleurolites, sandy clays and diatomites with coal streaks (Vatsev \& Pirumova, 1983; Vatsev, 1999; Ivanov, 2013). The fossil insects reported here were discovered in the Sivik Formation. They have been preserved as compression fossils in diatomite clays with only minor relief.

Based on the total content of the macroflora from all layers of the Sivik Formation, Bozukov (2002) has determined its age as Middle Miocene. That dating was also confirmed by the pollen analysis (Ivanov, 2004, 2012, 2013) and accepted in Nel et al. (2016) and Simov et al. (2021). Since the studied fossil insects ori- 


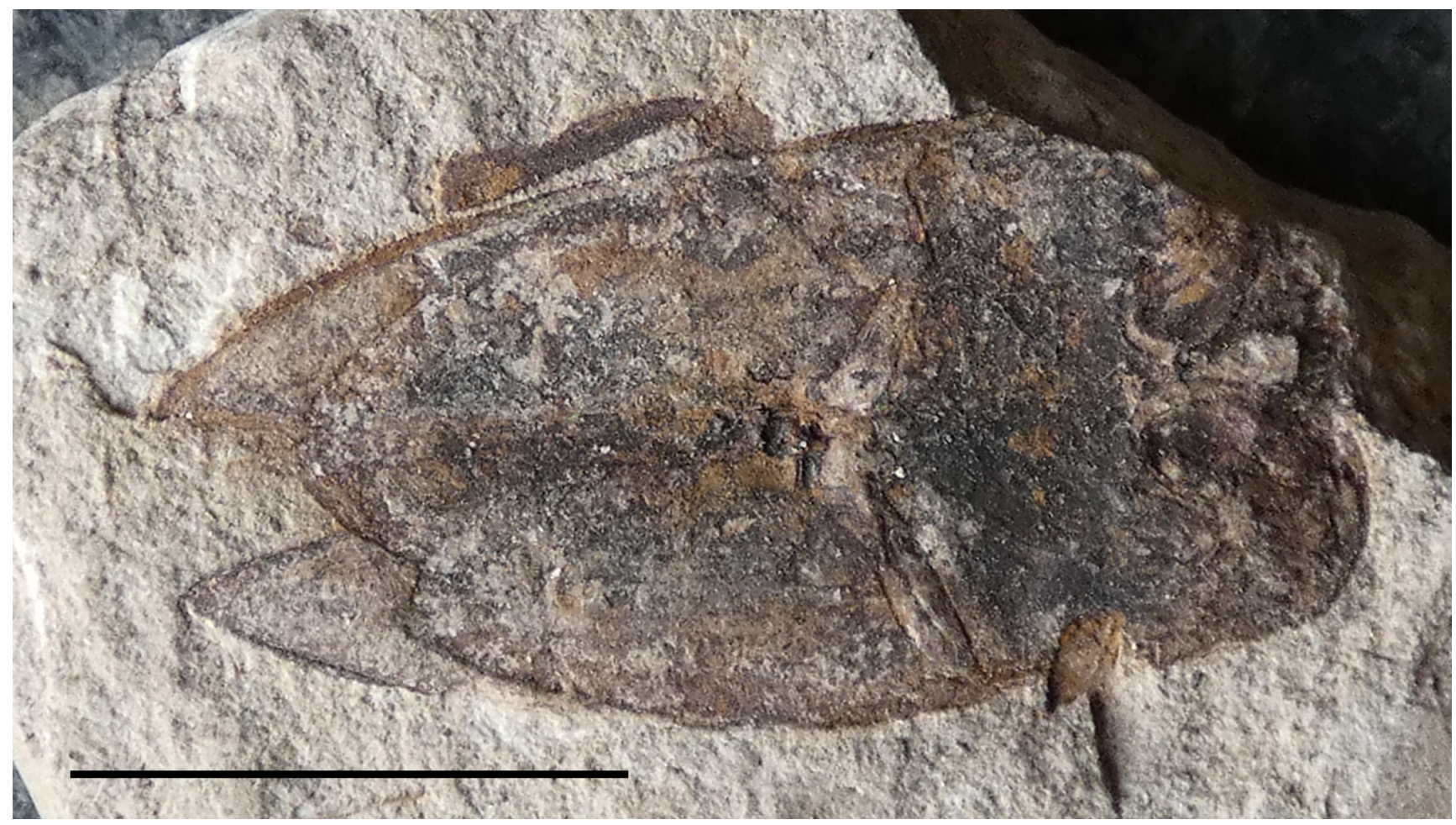

Fig. 1. Dicercini gen. sp. indet. (Coleoptera: Buprestidae): Cat-III-2151, Division of Palaeobotany and Palynology, Institute of Biodiversity and Ecosystem Research, Bulgarian Academy of Sciences, Sofia, Bulgaria. Scale $=10 \mathrm{~mm}$.

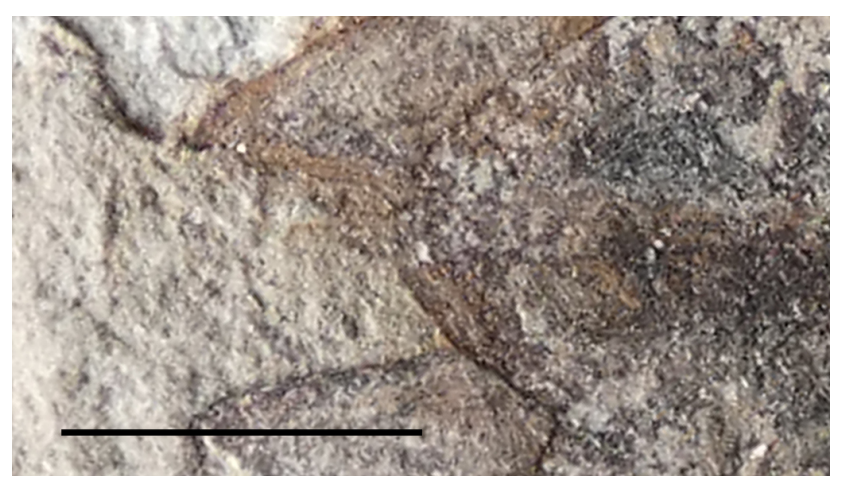

Fig. 2. Same, apical part of the abdomen with visible apical part of the aedeagus. Scale $=4 \mathrm{~mm}$.

ginated from the lower part of Sivik Formation, their age should be considered as Middle Miocene.

Specimens were observed in dry state and photographed with camera Panasonic Lumix FZ82. All structures were measured (in $\mathrm{mm}$ ) as preserved. The fossil specimens are deposited in the collections of the Division of Palaeobotany and Palynology, Institute of Biodiversity and Ecosystem Research, Bulgarian Academy of Sciences (IBER-BAS).

\section{Results and discussion}

Systematic palaeontology

Coleoptera Linnaeus, 1758

Buprestidae Leach, 1815

Dicercini Gistel, 1848

gen. sp. indet. (Figs 1-2)

Material: male, Cat-III-2151 (part), Division of Palaeobotany and Palynology, Institute of Biodiversity and Ecosystem Research, Bulgarian Academy of Sciences (IBER-BAS), Sofia, Bulgaria.

Description. Cat-III-2151 (part) (Fig. 1). Mediumto big- sized beetle, length $22 \mathrm{~mm}$, width $10.5 \mathrm{~mm}, 2.1$ times as long as wide. Dorsolaterally embedded, strongly compressed. Body brown to dark brown with darker parts of the pronotal disk and medial parts of the first $2 / 3$ of ventral terga. Head not preserved. Pronotum transverse, moderately cordate. Pronotum length 8.6 $\mathrm{mm}$ and width $10.5 \mathrm{~mm}$. Elytra obliquely truncate at humeri, sides then subparallel to mid length, arcuate to near apices and regularly arcuate just before apices. Elytra length ca. $15.5 \mathrm{~mm}$, width $5.5 \mathrm{~mm}$, length/width 
$=2.82$. Rather short and wide and finely punctato-striate. Hind legs with pale brown to brown femurs and darker tibia, robust; hind tibia $5 \mathrm{~mm}$ long. Last abdominal segment with broadly and gently arched apex. Partly extruded aedeagus is visible - widened in anterior half, narrowed in apical part (Fig. 2).

\section{Remarks}

The combination of the following features shows that the beetle undoubtedly belongs to family Buprestidae: body nearly cylindrical, slightly flattened, elongateovoid, cuneiform; pronotum irregularly quadrate, slightly narrowed in front and elytrae apically acuminate (Bellamy \& Volkovitsh, 2005). The big size (22 $\mathrm{mm}$ ), glabrous body, cordate pronotum, small scutellum, and more or less arcuate and finely punctato-striate elytra suggest it could be placed in the tribe Dicercini. Last abdominal segment with broadly and gently arched apex suggests the specimen is not of Chrysochroini. In general habitus the fossil beetle resembles much more representatives of the genera Lampetis Dejean, 1833 or Perotis Dejean, 1833 or other Dicercini. The incomplete preservation of the specimen does not allow species description or affiliation to exact genus.

The composition of the rich flora (Bozukov, 1998a, 1998b, 1999a, 1999b, 2000) supported the humid, warm-temperate to subtropical climate of this time interval (with temperatures above $15-16^{\circ} \mathrm{C}$, and precipitation above $1000 \mathrm{~mm}$ ) with frostless winters, while the vegetation corresponds to the mixed mesophytic forest (Ivanov, 2012, 2013). In terms of floristic composition, the fossil flora of Satovcha is closest to "evergreen broadleaved forest" and "mixed semi-evergreen forest" of Southeast Asia (Bozukov, 2001, 2002; Ivanov, 2012, 2013). Such conditions correspond well with the climatic requirements of the extant representatives of the above-cited buprestid genera. Lampetis and Perotis and Dicercini at all were widely distributed in present times in the tropic-subtropic regions of Asia, Africa and both Americas.

The discoveries of first fossil Buprestidae from the Middle Miocene in Bulgaria is of palaeobiogeographical importance. Currently, this is one of the oldest Miocene fossil records of Dicercini in Europe. A few described fossil species, Perotis bruckmanni Heer, 1862; P. lavateri Heer, 1847; Capnodis antiqua Heer, 1847; C. puncticollis Heer, 1847 and C. spectabilis Heer, 1862, originated from the locality of Öhningen
(South Germany) with the age assigned to the Late Miocene (Selmeier, 1990; Lutz, 1997; Fikáček \& Schmied, 2013).

\section{Acknowledgements}

The authors are greatly indebted to Mark Volkovitsh (Zoological Institute, Saint Petersburg) and one anonymous reviewer for reviews and valuable critical comments and remarks.

\section{References}

Bellamy C.L. 2008 A World Catalogue and Bibliography of the Jewel Beetles (Coleoptera: Buprestoidea) Volume 2: Chrysochroinae: Sphenopterini through Buprestinae: Stigmoderini. 626-1260.

Bellamy C.L., Volkovitsh M.G. 2005 Chapter 17. Buprestoidea Crowson, 1955, pp. 461-468. In: Beutel R.G., Leschen R.A.B. (eds) Handbook of Zoology, Volume IV, Arthropoda: Insecta, Part 38, Coleoptera, Beetles, Volume 1: Morphology and Systematics. W. de Gruyter, Berlin, New York, 567 pp.

Bozukov V. 1998a Miocene macroflora of the Satovcha Graben (Western Rhodopes). I. Systematics. 1. Equisetophyta, Polypodiophyta, Pinophyta. Phytologia Balcanica 4 (1-2): 3-12.

Bozukov V. 1998b Miocene macroflora of the Satovcha Graben (Western Rhodopes). I. Systematics. 2. Lauraceae, Magnoliaceae, Cercidiphyllaceae, Hamamelidaceae, Ulmaceae, Moraceae. Phytologia Balcanica 4 (3): 3-12.

Bozukov V. 1999a Miocene macroflora of the Satovcha Graben (Western Rhodopes). I. Systematics. 3. Fagaceae, Betulaceae. Phytologia Balcanica 5 (1): 3-13.

Bozukov V. 1999b Miocene macroflora of the Satovcha Graben (Western Rhodopes). I. Systematics. 4. Myricaceae, Juglandaceae, Theaceae, Salicaceae, Ericaceae, Myrsinaceae, Tiliaceae, Sterculiaceae, Fabaceae, Meliaceae, Anacardiaceae, Rutaceae, Aceraceae, Sapindaceae, Styracaceae, Cornaceae. Phytologia Balcanica 5 (2-3): 47-62.

Bozukov V. 2000 Miocene macroflora of the Satovcha Graben (Western Rhodopes). I. Systematics. 5. 
Magnoliophyta: Araliaceae, Aquifoliaceae, Celastraceae, Rhamnaceae, Vitaceae, Apocynaceae, Caprifoliaceae, Convolvulaceae, Macclintockia; Smilacaceae, Cyperaceae, Sparganiaceae, Typhaceae. Phytologia Balcanica 6 (1): 15-29.

Bozukov V. 2001 Miocene macroflora of the Satovcha Graben (Western Rhodopes). II. Paleofloristic, paleoecological and phytogeographical analysis. Phytologia Balcanica 7 (1): 13-33.

Bozukov V. 2002 Miocene macroflara of the Satovcha Graben (Western Rhodopes). III. Comparative analysis of the Satovcha paleoflora with benchmark European macrofloras. Geological age of the paleoflora. Phytologia Balcanica 8 (2): 165-180.

Fikáček M., Schmied H. 2013 Insect Fauna of the Late Miocene Locality of Öhningen (Germany) Less Diverse Than Reported: An Example of the Hydrophilid Beetles (Coleoptera). Journal of Paleontology 87 (3): 427-443.

Heer O. 1847 Die Insektenfauna der Tertiärgebilde von Oeningen und von Radoboj in Croatien. Erster Theil: Käfer. 229 pp.

Heer O. 1862 Beiträge zur Insektenfauna Oeningens: Coleoptera. Geodephagen, Hydrocanthariden, Gyriniden, Brachelytren, Clavicornen, Lamellicornen und Buprestiden. Natuurkundige Verhandelingen van de Hollandsche Maatschappij der Wetenschappen te Haarlem 16 (2): 1-90.

Ivanov D. 2004 Pollen of some exotic plants in the Neogene of Bulgaria. Acta Palaeobotanica 44 (1): 69-77.

Ivanov D. 2012 New palynological data on some subtropical floristic elements of the Middle Miocene of Bulgaria - palaeoecological and palaeoclimatic significance. In: Petrova A. (ed.) Proceedings of the
VII National Conference on Botany 29-30.09.2011, Sofia, Bulgarian Botanical Society, Sofia, 287-296. (In Bulgarian)

Ivanov D. 2013 Palynological data on the Middle Miocene vegetation from Satovcha Basin, SW Bulgaria. In: Țabără D. (ed.) Ninth Romanian Symposium on Paleontology Iași, 25-26 October 2013. Abstract Book, University of Iași: 62.

Lutz H. 1997 Taphozönosen terrestrischer Insekten in aquatischen Sedimenten - ein Beitrag zur Rekonstruktion des Paläoenvironments. Neues Jahrbuch fuer Geologie und Paläontologie Abhandlungen 203: 173-210.

Nel A., Simov N., Bozukov V., Marinov M. 2016 New dragonflies and damselflies from Middle Miocene deposits in SW Bulgaria (Insecta: Odonata). Palaeontologia Electronica 19.3.35A: 1-13.

Selmeier A. 1990 Die Molasseflora von Öhningen. In: Weidert W.K. (ed.) Klassische Fundstellen der Palaöntologie, Band 2. Gold-schneck-Verlag, Korb, 214-220.

Simov N., Langourov M., Pavlova A., Hubenov Z., Bozukov V. 2021 First record of fossil Diptera (Insecta) in Miocene deposits in Bulgaria. Comptes rendus de l'Académie bulgare des Sciences 74 (2): 233-240.

https://doi.org/10.7546/CRABS.2021.02.10

Vatsev M., Pirumova L. 1983 Lithostratigraphy of Tertiary sediments from the Satovcha Graben. Annuaire de l'École supérieure des Mines et de Géologie, Sofia 2: 169-179. (In Bulgarian)

Vatsev M. 1999 New data about stratigraphy of the Neogene rocks of the South-western Rhodopes, Bulgaria. Review of the Bulgarian Geological Society 60 (1-3): 127-137. (In Bulgarian) 